\section{N. Subba Rao \\ I. Saroja Nirmala \\ K. Suryanarayana}

Published online: 4 January 2006

(C) Springer-Verlag 2006

The online version of the original article can be found at http://dx.doi.org/10.1007/ s00254-005-1306-2

N. Subba Rao $(\varangle) \cdot$ I. Saroja Nirmala

K. Suryanarayana

Hydrogeology Laboratory,

Department of Geology,

Andhra University,

Visakhapatnam 530003 , India

E-mail: srnandipati@rediffmail.com

Tel.: +91-0891-2844716

Fax: +91-0891-2755324

\title{
Groundwater quality in a coastal area: a case study from Andhra Pradesh, India
}

\section{Environ Geol (2005). DOl: 10.1007/s00254-005-1306-2}

In the online version in the second paragraph below the heading "Factors controlling groundwater quality" and in the print version on page 548 , 2nd column, 2nd paragraph, the first sentence should read:

Though the groundwater samples 1, 2, 3, 12 and 19 show both fresh,
TDS $<1,000 \mathrm{mg} / \mathrm{l}$, (sample 12) and brackish, TDS $>1,000 \mathrm{mg} / \mathrm{l}$, (samples 1-3 and 19) categories (Table 1), the ratios of $\mathrm{Ca}^{2+}: \mathrm{Mg}^{2+}<1$ (sample 19), TA:TH $<1$ (samples $1-3$ and 12) and $\mathrm{Cl}^{-}: \mathrm{HCO}_{3}^{-}>1$ (samples $1-3$ and 12) in groundwaters (Table 3 ) suggest the influence of seawater. 